\title{
Externalization of Systematic Values of Wahyu Hidayatullah - in Constructing Miniature Islamic Civilization
}

\author{
Irfan Yahya ${ }^{1}$, M Tahir Kasnawi $^{1}$, Suparman Abdullah ${ }^{1}$, Hasbi $^{1}$ \\ ${ }^{1}$ Faculty of Social Science and Political Science, Hasanuddin University, Indonesia \\ Received: July 15, 2021 \\ Received in Revised: August 12, 2021 \\ Accepted: August 28, 2021
}

\begin{abstract}
The values of the Systematic of Revelation as the basic -/pattern according to what the Hidayatullah - understands, believes, and practices in carrying out the process of social creation of a miniature Islamic Civilization are the topic of this study. The purpose of this research is to examine the process of externalizing Systematic Wahyu ideals like the Hidayatullah -' - in carrying out social construction activities in a tiny Islamic civilisation. This research looks at the reality of the Hidayatullah - congregation's consciousness, which reveals things about reality and the interpretation of the Systematic of Revelation as a -/archetype that is employed as a social construction reference. The process of externalizing the values of Systematic Revelation is a conscious, structured, and systematic effort by Hidayatullah actors to create humans as abdullah (servants of Allah) and caliph (representatives) of Allah SWT on earth, based on revelation's guidance, in order to build Islamic civilization. The Islamic boarding School Campus is employed as a model of Islamic civilisation, with all cadres, members of the congregation, and their students demonstrating faith in all parts of everyday life. Internalized Hidayatullah players objected to the values that are consistently presented and then generate cadres capable of providing enormous advantages to society. This corresponds to Berger's notion that human selfhood cannot possibly remain silent within itself, in a closed sphere, before moving outside to express itself in the world around it. Externalization is essentially what human selfhood is accomplishing.
\end{abstract}

Keywords: Social construction, Islamic Civilization, Systematic Revelation

\section{Introduction}

One of the most notable intellectual trends of the twentieth century was the growing interest in religion, which coincided with a broad understanding that religious belief, as conventionally defined, had dropped substantially in an inherent sense among most members of society. This is evident and can be as broad as feasible in terms of the public interest in questions quickly related to religious people's efforts to reform and adapt their religious beliefs and institutions in light of modern-day changes (Utama \& Paramita, 2018).

Religion is one of the most prominent and wide-reaching social institutions, touching and shaping virtually every sphere of culture and society (Ives \& Kidwell , 019).Religion has played an important role in humanity's quest to establish a better world or to put it another way, how a social system uses religion as a point of reference to carry out social construction (Kastoryano 2004). Religion remains a central element of modern life, shaping people's worldviews, moral standards, family lives, and inmany nations, their politics (Kelley \& De Graaf, 1997). Religion has been the subject of several studies and research, particularly in the field of sociology (Carnesecca, 2016). A major goal of the social sciences is to understand how groups responded and overcame these survival pressures, with implications for the evolution of human diversity (Jackson et al., 2020) 
Robertson (1986) suggests that these prominent figures were Max Weber and Emile Durkheim, who, although differing in their particular interests and in many conclusions, had a common desire to understand and express or expose the social and cultural characteristics of industrial societies. While the two sociologists do not deny that traditional forms of religion are on the wane, they are wary of evolutionists who address this trend. Weber and Durkheim were preoccupied with the issue of how societies can function without religion.

A considerable literature has grown up concerning general trends in the development of organizational forms, and especially the transition from bureaucratic to post-bureaucratic structures and processes (Pollitt, 2009). Weber, credited for having founded organizational theory, does not so incidentally, as a study of the ideal type of bureaucracy (Clegg, 1994).. In Weber's emphasis on the importance of bureaucratic organizations and the relations between rational power and legal power and the decline in the sense of charismatic leadership, in his discussions of the notion of salvation and most clearly in his observations of the modern world which are not dazzling. or not tantalizingly we can see parallels or parallels with Durkheim's concern with themes such as the great social, economic and political processes associated with the division of labour; with the distinction between aspects of societies that are sacred (holy or sacred, spiritual) and profane (worldly, physical); about the usa only to seek modern parallels for the spiritual beliefs and symbols of primitive societies and societies of pre-industrial times; and about his interest in issues of group cohesion, individual identity and suicide. Weber and Durkheim's preoccupations, as well as the worries and interests of many of their contemporaries, are inextricably linked with their respective studies of religion, despite the fact that Weber published far more on the subject than Durkheim.

Over the previous decades a number of sociologists have revived this kind of interest in religious phenomena. While there are significant differences in viewpoints and findings, we can detect an interest in religious phenomena in the same broad setting as Weber and Durkheim in the work of sociologists such as Peter L. Berger, Thomas Luckmann, Guy Swanson, and Robert Bellah (Utama \& Paramita, 2018).

In order to perform this research, Peter L. Berger's perspective on religion as a social reality and social interpretation of reality was used. Every human society, according to Berger (1991), is a global development effort. Religion plays a unique role in this endeavor. Society is a dialectical phenomena, with three momentums or steps: externalization, objectivation, and internalization. An empirically adequate perspective of society will arise from a careful study of these three momentums. The focus of this research is solely on the externalization momentum. Religion legitimizes social institutions by giving them a legitimate ontological status, that is, by placing them within a sacred and cosmic frame of reference. The constructions of the history of human activity are seen from a high point which, according to its own definition, transcends history as well as humans (Rofiqoh 2020).

In the framework of this sociological study, religion is defined not by what and how its teachings and beliefs are expressed, but by how those beliefs and teachings are carried out and shown in the behavior of its members in everyday life. The Sociology of Religion was the study of human religiosity in the behavior of the world of reality at the time. According to Durkheim, religion can only be understood by examining the social role it plays in the absence of a community of people united by rituals and shared beliefs (Turmudi 2015).

On the one hand, Indonesia's cultural diversity has the potential to create a large national community, but it also has the potential to be a divider and a source of lateral tensions, even in democracy (Darwis et al., 2021). Various cooperation among stakeholders in the administration of government is also carried out as an effort and response of the government in the activities of handling public problems (Ahsan et al. 2020). Hidayatullah is one of the social institutions

Copyright $($ C 2021, Journal of Asian Multicultural Research for Social Sciences Study, Under the license CC BY-SA 4.0 
based on Islam, apart from being a social institution, it is also a social system that takes part in the midst of Indonesian society. (Arifin 2019). Founded on January 7, 1973 in the form of a boarding school, then developed with various business charities in the social, religion, education and economic fields and spread to various regions in all provinces in Indonesia (Ahmad 2018). Hidayatullah changed his organizational form into a social organization and declared himself an Islamic struggle (Rachman \& Herianingrum 2016). Until date, the Hidayatullah has been operating in 353 regencies/cities across Indonesia, with around 600 Islamic boarding schools. The movement's rhythm and pulse have been present and active in 24 regencies/cities, 45 Islamic boarding schools, and 6 representatives abroad.

The Hidayatullah Community Organization, as one of the social systems, carries out a miniature social construction of Islamic civilization by referring to the systematic pattern of revelation, a method used by the prophet Muhammad SAW and his companions in constructing the first Islamic civilization on earth in Medina.

Organizational performance is basically the result of the output, outcome, impact, and benefit of the policy process created by an organization (Pasinringi et al., 2020). According to Nashirul Haq (2019: 5), Hidayatullah is an Islamic organization founded on the Qur'an and prophet Muhammad's rules (Damanhuri 2020) . In carrying out the social construction of miniature Islamic civilization which was demonstrated directly in an Islamic boarding school area, the Hidayatullah refers to the systematic pattern of revelation as described above. Islamic civilization, according to the Hidayatullah organization, is an endeavour to show belief (iman) in all facets of daily life (Peribadi, 2017)

This is where Hidayatullah's organizational management strength rests, as he is capable of combining two components at the same time. The element of leadership as a supplier of the spirit of struggle and the consolidation of the six organizational pillars that make the Hidayatullah always flexible to adapt to all conditions, including the ability to "surf" in the current era of disruption to carry out social construction of Islamic civilization by making the Islamic boarding school area a miniature Islamic Civilization.

\section{Methods}

The phenomenological method was employed in this study. Phenomenology is an attempt to depart from the scientific method which assumes that the existence of a reality is unknown to people in ordinary experience (Knaack, 1984). As a result, the focus of this study is on Systematics of Revelation that the Hidayatullah Organization believes and practices in carrying out the process of social creation of a miniature Islamic Civilization. This study examines the reality of the awareness of the Hidayatullah congregation which shows things about reality and the interpretation of the Systematic of Revelation that is used as a reference for carrying out social construction from Berger's perspective.

The phenomenological method in this study directed the study to be more focused, so that a specific theme was born about the process of social construction of miniature Islamic civilization. Referring to the systematic pattern of revelation carried out by the Hidayatullah.

For exploring and interpreting the significance of the activities of the Hidayatullah social being that emerges in front of the researcher, the phenomenological technique is regarded appropriate. Furthermore, the phenomenological technique aids in the comprehension of social reality in the form of the Hidayatullah Community Organization congregation's conduct as revealed to researchers. The phenomenological method makes researchers believe that whatever is seen and recorded when conducting this research is the reality that really happened in the Hidayatullah entity. Researchers can also uncover hidden truths regarding the systematics of Revelation in the Hidayatullah congregation's beliefs, which they can 
subsequently divulge by publishing study findings, resulting in a fresh understanding of the situation.

Data collection in the form of observation, interviews and documentation, allows researchers to be directly involved in the field, through direct techniques with the management and congregation of the Hidayatullah, as well as being able to conduct intense and in-depth data so that they can verbally capture what was conveyed by informants in research consisting of the founders., administrators and Hidayatullah students about their understanding of the Systematics of Revelation. For this reason, Systematic Revelation is a noumena that appears not only to researchers but also to Hidayatullah. Husserl states that every phenomenon always consists of subjective activities and objects as the focus, so Hidayatullah's subjectivity is important to study (Husserl 2001). This is because the subjective activity leads to the object, in this case the Systematic of Revelation in Hidayatullah's understanding. Furthermore, the subjective activity interprets, gives identity, and forms the meaning of the object. Subjective activity and object as the focus cannot be separated from this research. With a phenomenological approach, the steps of this research are sought to meet the standard values and prerequisites needed in phenomenological studies; determine phenomena, collect data, analyze data and defend findings

\section{Resulta and Discussion}

\section{The Process of Externalizing the Systematic Values of Revelation in the Efforts of Miniature Social Construction of Islamic Civilization}

The externalization process is used to study the process of externalizing the values of Revelation Systematics as Hidayatullah's in carrying out social construction activities of a miniature Islamic civilization in which the Islamic boarding School campus is employed as a teaching tool.

According to Berger (1991), externalization is an anthropological imperative. Man is inconceivable without the ongoing outpouring of himself into the universe in which he lives, according to our empirical understanding. However, it is impossible to envisage the human self remaining stationary within itself, in a closed sphere, and then moving outward to express itself in the world around it. Externalization is fundamental to human selfhood, and it has been since the beginning.

Hidayatullah recognizes that building Islamic civilization must begin with the individual self, the family, and the process of internalizing the revealed values of Quran, as previously described, and only then move on to darkness to enlighten (externalize) the middle. in the community as a community.

As an actor preparing to enter the arena, his soul must be compatible with the Qur'an. Starting with the internalization process that these three chapter in Quran must undergo. After this process is well formed, it will automatically find something new in the actor's life, when the actor feels calm, his soul is really clean, happy without him talking, just silence has given influence, in the social system the presence of an actor like this has had a tremendous effect, a positive influence.

As a result, it is unavoidable to enter the process of Quran, or externalization; nonetheless, the construction of the previous three suras has a favorable effect. Because of the construction of the previous three chapter in Quran, silence has a beneficial influence, especially when speaking; it will give birth to a narrative that feels different than usual. The wording may be identical, but the feel may differ. For example, being called by thugs and called by the teacher with the same sentence, the text can be the same, but the effect on the soul is different. This is 
the picture of the effect of people whose souls have internalized the values of revelation. That's a fact that we often encounter in social life.

Until now with that spirit, Hidayatullah spread throughout the archipelago. Even at the opening ceremony of the 2000 Hidayatullah National Conference in Indonesia, Vice President Jusuf Kalla declared Hidayatullah as the fastest growing mass organization. In various regions, there have been many development activities and business charities which have become the actualization of the activities of Hidayatullah activists and members. Hidayatullah schools and Islamic boarding schools began to be in great demand by the public.

In addition to being a provider of educational facilities from kindergarten to university, Hidayatullah also provides social and da'wah services, including services for organizing corpses, spreading da'i/lecturers and mosque imams. From social actions, Hidayatullah often collaborates with all parties who carry out movements when there is a natural disaster. Hidayatullah is open to dialogue with any group, it is not exclusive. Through the actor often provides systematic studies of revelation, such as the study of Quran. He also often lectured on the life of civil society, fraternizing the Ansar and the Muhajirin when the Prophet first migrated on the basis of faith. If this has been established, the community will be easily directed with good morals in Islam. Hidayatullah is not only known by the public through his religion movement, study and social works, he is also widely known by the public through trust financing (Baitul Mall) and Voice of Hidayatullah magazine.

In an effort to strengthen this da'wah (an appeal to understand Islam) service, Hidayatullah targets all levels of society, especially those who are still illiterate in the Qur'an, now the Hidayatullah Central Executive Board has launched the Hidayatullah Qur'an House Program $(\mathrm{RQH})$. The launch of this program carries the big theme 'Building Indonesia with the Qur'an'. With the Hidayatullah Qur'an House Program (RQH), Hidayatullah hopes that there will be an acceleration of community development at some points that do not yet have the opportunity.

Chairman of the Hidayatullah, Mr. Nashirulhaq, Lc, in his remarks at the inauguration of the program published on the Hidayatullah.or.id website (February 24, 2021) said that currently Hidayatullah is structurally present in 374 districts/cities, and Hidayatullah Islamic boarding schools are present in more than 600 points. In addition, Ustadz Nashirulhaq expressed his belief that with the targets that have been jointly announced, all components involved, God willing, Hidayatullah's commitment will be present in all districts and cities.

Mr. Nashirulhaq, Lc reminded Qur'an teachers that the work of teaching the Qur'an is a huge gift, and they should be proud to do it. As a result, let us work together to increase people's spirits and motivation so that they might be proud to be Qur'an preachers. People who want to become rabbis should do so. And in the world, this is a pretty honorable career.

Humans, according to Berger (1991), must create their own reality. As a result, the process of making the world is a direct result of human biological construction, rather than a nonbiological event. Man, in the course of building the world, specializes in his impulses and gives himself stability via his own labor.

According to the findings of the study, Hidayatullah's position was extremely advantageous; in addition to living at the heart of the town, Hidayatullah was able to assume social duties. Rarely do we get a boarding school like this. On average Islamic school choose areas that are a bit far from settlements, and tend to focus only on education. Hidayatullah's da'wah is growing quite rapidly and is going well, it is very well accepted by all mosques and the community, because the da'wah that is delivered is general in nature, no one complains. The economic side is also felt, many have given birth to independent entrepreneurs and this is what the government wants. Residents and Hidayatullah congregation are quite integrated with the 
community, work hand in hand if there is a disaster that occurs in South Sulawesi, even with the government, police officers, all coordinate with each other, visit each other to build communication (Headman Tamalanrea, 2021).

According to this study, people who contact directly with Hidayatullah cadres feel at ease and recognize the presence of cadres in the society. This may be observed in the function of cadres in giving community da'wah, which is diffused throughout mosques and favorably appreciated by the community. It even fosters communal cohesion by offering social aid to those who Hidayatullah education program economic empowerment have been harmed by calamities. Furthermore, the assists the government in promoting community.

The hidayatullah actors who have gone through the internalization process have objectified the values that have been methodically disclosed, resulting in cadres capable of providing significant social benefits. This is in keeping with Berger's statement that the human ego cannot be envisioned remaining motionless within itself, in a closed sphere, and then moving out into the world to express itself. Externalization is essentially what human selfhood is accomplishing

\section{Conclusion}

The process of Externalizing the values of Systematic Revelation, particularly those found in Quran, is manifested in Hidayatullah actors' daily lives as they carry out social construction efforts of miniature Islamic civilization through the mainstream of tarbiyah and da'wah movements. Hidayatullah created the Hidayatullah Qur'an House $(\mathrm{RQH})$ initiative through the Indonesian Dai Brotherhood as a planned and methodical conscious effort to expedite the development of public preaching throughout the country. Hidayatullah also infiltrated rural sections of the community through Baitul Mall (BMH) as a sort of community empowerment service. If the study's findings are compared to Berger's theory of Social Construction and the framing of the problem in the research object, it is discovered that there are disparities in epistemic footing. Berger perceives religion as values that are deteriorated by secular values in society's fundamental dialectic, however the findings of this study show that religious values can be used as the foundation for establishing a civilisation that persists in society without being degraded by secular values. With evidence from the pattern of interaction and behavior of the Hidayatullah congregation (as a social system), this study produces one argument that: Systematics of Revelation has become a reference/method in carrying out the miniature social construction of Islamic civilization with a fundamental dialectical process of three momentums, namely internalization, objectivation and externalization.

\section{References}

Ahmad, A. K. (2018). Pesantren Hid Ayatullah Gunung Tembak Dan Issu Terorisme. AlQalam, 13(1), 1-18.

Ahsan, S. C., Samad, M. A., \& La Husein Zuada, N. (2020). Implementation of E-Government Policies: Case Study of Goods and Services Procurement in Buol Regency, Central Sulawesi, Indonesia. saudijournals.com

Arifin, B. (2018). Strategi Komunikasi Dakwah Da'i Hidayatullah dalam Membina Masyarakat Pedesaan. Communicatus: Jurnal Ilmu Komunikasi, 2(2), 159-178.

Carnesecca, C. (2016). Religious borderlands: Sociology of religion in conversation with its disciplinary neighbors. Sociology of Religion, 77(3), 225-240.

Clegg, S. (1994). Weber and Foucault: Social theory for the study of organizations. Organization, 1(1), 149-178. 
Damanhuri, M. P. Pembelajaran Baca Kitab Pendekatan Sistematika Nuzulnya Wahyu (Snw). e-jurnal.stail.ac.id

Darwis, D., Sasterio, S., \& Samad, M. A. (2021). Politics of Religious Identity in General Elections Regional Head of Sigi District, Central Sulawesi Province. Journal Dimensie Management and Public Sector, 2(2), 39-50.

Husserl, E. (2001). Psychologie phénoménologique. philpapers.org

Ives, C. D., \& Kidwell, J. (2019). Religion and social values for sustainability. Sustainability Science, 14(5), 1355-1362.

Jackson, J. C., Gelfand, M., \& Ember, C. R. (2020). A global analysis of cultural tightness in non-industrial societies. Proceedings of the Royal Society B, 287(1930), 20201036.

Kastoryano, R. (2004). Religion and incorporation: Islam in France and Germany. International Migration Review, 38(3), 1234-1255.

Kelley, J., \& De Graaf, N. D. (1997). National context, parental socialization, and religious belief: Results from 15 nations. American Sociological Review, 639-659.

Knaack, P. (1984). Phenomenological research. Western journal of nursing research, 6(1), $107-$ 114.

Pasinringi, A., Darwis, D., \& Samad, M. A. (2020). Conflict of Government Policy in Tolitoli Regency, Central Sulawesi Province. International Journal Papier Public Review, 1(2), 47-55.

Peribadi, P. (2017). The Strategy Of Empowerment Based On Esq Power: A Social Innovation In The Poverty Overcoming. El Harakah, 19(2), 227.

Pollitt, C. (2009). Bureaucracies remember, post-bureaucratic organizations forget?. Public Administration, 87(2), 198-218.

Rachman, P., \& Herianingrum, S. (2016). Pemberdayaan Wakaf Tunai Pada Baitul Maal Hidayatullah Di Surabaya Dalam Bidang Pendidikan. Jurnal Ekonomi Syariah Teori dan Terapan, 3(8), 669-682.

Rofiqoh, Y. I. A. (2020). Konstruksi Realitas Sosial, Sintesa Strukturalisme Dan Interaksional Komunikasi Dakwah Islam Di Era Post Truth. Al-Ittishol: Jurnal Komunikasi dan Penyiaran Islam, 1(2), 71-79.

Turmudi, Imam. 2015. "Menimbang Gagasan Bryan S. Turner Tentang Islam.” Teosofi: Jurnal Tasawuf Dan Pemikiran Islam 3(1):60. doi: 10.15642/teosofi.2013.3.1.60-89

Utama, I. W. B., \& Paramita, I. G. A. (2018). agama Dan Fenomena kegilaan. Vidya Wertta: Media Komunikasi Universitas Hindu Indonesia, 1(1), 107-113. 